\title{
Performance Evaluation of Listed Companies in New-Energy Automotive Industry
}

\author{
Zexuan Lu, Hongsheng Xia \\ Management College, Jinan University, Guangzhou, China \\ Email: luzexuan2008@163.com
}

Received 20 October 2014; revised 15 November 2014; accepted 24 November 2014

Copyright (C) 2014 by authors and Scientific Research Publishing Inc.

This work is licensed under the Creative Commons Attribution International License (CC BY). http://creativecommons.org/licenses/by/4.0/

c) (i) Open Access

\begin{abstract}
As one of the national strategic emerging industries, new-energy-automobile industry has been caused people's attention increasingly. Therefore, improving the new energy industry listing corporation performance, not only can alleviate the pressure on energy and the environment, but also can conducive to accelerating the transformation and upgrading of the automotive industry. Moreover, it can foster new economic point of growth and international competitiveness. This essay uses the super efficiency DEA model and Malmquist index method to analyze the performance of new-energy-automotive industry listing corporation. The data is from Year 2011 to 2013. Finally according to the conclusion of the empirical research, this paper made several suggestions to improve the operational efficiency of China's new energy automobile enterprises and promote newenergy-automobile industry.
\end{abstract}

\section{Keywords}

New-Energy-Automobile Industry, Performance Evaluation, Super-Efficiency DEA Model, Malmquist Index

\section{Introduction}

As the pollution of world becomes more and more serious, the energy crisis is coming. Moreover, along with the sustainable development of low carbon economy, new energy automobile industry has get more attention because of its energy saving and environmental protection. Since our country has added into WTO, the new energy automotive industry in our country has made a significant breakthrough. In 2010, the State Council listed the new energy automotive industry as the strategic emerging industry which leading the development of economic. In 2012, the State Council put forward to seize the opportunity to speed up the cultivation and development of 
new energy automotive industry, because it can not only alleviate the pressure of energy and environment, but also help to accelerate the transformation and upgrade of the automotive industry. According to some scholar, in the 2014 and 2015, China new energy automobile industry will increase explosively [1]. Therefore, it is significant to develop new energy automotive industry as it can implement the national energy-saving emission reduction strategy and change the mode of economic growth.

However, the development of Chinese new energy automobile industry still faces many challenges, especially the insufficient investment of the core technology field. And it has not yet formed a perfect system of technology innovation. The commercialization of new energy automotive progressed at a slow pace. The new energy automotive products in high cost, the key technology has not developed, the new energy automotive industry is still in the initial stage and other problems that exist in enterprises, such as inadequate investment, local protectionism and other specific issues. Some scholars have found the effect of path dependence unavoidably exists in the process of new energy automotive industry development, And will lead automobile industry to lock in traditional technical and institutional development path [2]. Under this background, it is an important research topic of how to improve operating efficiency of the new energy automobile enterprise and how to enhance the competitiveness of new energy automobile industry.

Based on the above background, firstly, this article starts from view of operating efficiency, and use s super efficiency DEA model to measure the operating efficiency of the new energy automotive listing corporation. Secondly, the further research is to study the dynamic change of total factor productivity (TFP) of new energy automobile industry listing corporation by using the Malmquist index method. The purpose is to find out the factors that influent the operating efficiency of new energy automobile enterprises. Thereby to improve the operating efficiency, enhance the overall competitiveness, and promote the development of new energy automotive industry.

\section{Literature Review}

With the government's strong support and promotion, the new energy automobile industry is booming. In recent years, scholars at China and abroad have made lots of research on the new energy automotive industry from different angles according to different research purposes. Nevertheless, these researches mainly focus on qualitative research on the development of new energy vehicle technology and industrialization namely. The research of quantitative research on the new energy automobile industry and enterprises is rare, needless to say the research of new energy automotive industry business performance of the company.

The research of foreign scholars on automobile enterprise efficiency and influence factors is earlier. SeemaSharma (2006) [3] studied India automobile industry by using the method of total factor productivity index analysis, and further explored the influence factors of automobile industry efficiency. Papahristodoulou (1997) studied the production efficiency of German car enterprises using DEA model [4]. Many scholars used DEA model to analyze the traditional automobile industry or the automotive component manufacturing production efficiency, and put forward some suggestions and countermeasures to improve the production efficiency of automobile enterprises (R. J. Orsato and P. Wells, 2007; Saranga, 2009; Nandy, 2011) [5]-[7].

Research on automobile enterprises efficiency of Chinese scholars was later. Yong Wang (2010) studied the efficiency of automobile enterprises by using the DEA method., and come to the conclusion that the total factor productivity of auto mobile industry listing corporation was in an upward trend between 2001 to 2008 [8]. In addition, some scholars found that technical efficiency contributed greatly on total factor productivity of China's automobile enterprises (Zenghui Li, 2012, Xianjin Wu, 2011) [9] [10]. What had discussed above were the traditional research in the automotive industry, the researchs for new energy automobile industry were quite few, not to mention about the study on the performance of new energy automobile enterprises. Recently, the study mostly focued on its industrial policy, enterprise strategy and regional development, For instance, Yang Ping and Ke Chuan Yi (2011) [11] made SWOT analysis of new energy vehicles. They concluded that the new energy automotive industry should establish industry alliance, integrate the advantage resources to the development of new energy vehicles in China; increase investment in research and development, increase policy subsidies, improve the supporting facilities, strengthen international cooperation and so on. There were scholars also making qualitative research on new energy vehicles, Jing Ruan (2010) [12] used comparative analysis and expert scoring method on the basis of evaluation index system of new energy vehicle, and further used fuzzy comprehensive evaluation method to judge comparison of the advantages and disadvantages of its development, finally obtained the long-term new energy technology development route. In addition, some scholars established inputoutput index system to study the technology innovation efficiency of new energy automotive industry (Wang 
Wei, 2013) [13] [14]. The business model is the key to the industrialization of new energy vehicles. In order to construct the need for new energy vehicles business model. We should entail the explicit priorities, macroguidance and coordinating the related interests [15]. As the battery is the critical part of new energy vehicle, some scholars studied research on the performance and service life of batteries membrane of new energy automotive [16] [17]. Moreover, many scholars focus on the analysis of policies for new energy vehicle by making researches on the problems and challenges in China's new energy vehicle industry [18]-[21].

By sorting out the early scholars study on the new energy automotive industry we found that, from the qualitative perspective, the prior analysis of new energy vehicles is lack of objective data of enterprise input and output. Therefore, this paper will analyze the static and dynamic efficiency of new energy automobile industry listing corporation by using the method of super efficiency DEA model and Malmquist index. Thus this paper will put forward some reasonable suggestions to improve the performance the new energy automotive industry and enhance the core competence of the new energy automotive list companies.

\section{Research Methods and Data Processing}

By reading literature we found that scholars who studied on the management efficiency of enterprises were more likely to adopt the DEA model, however most of the existing DEA model has short comings: Firstly, if there are more than one effective DMU it cannot distinguish them effectively. Secondly, DEA model cannot study the dynamic changes unit efficiency. Based on this, this paper uses the method of super efficiency DEA to compare of multiple efficiency DMU, and uses the Malmquist index approach to analyze the dynamic efficiency of total factor productivity of new energy automobile industry listing corporation.

\subsection{The Super Efficiency DEA Model}

The super efficiency DEA model was composed by Andersen and Pelersen in 1993 which based on the DEA model. The model can compare the efficiency between the various effective DMUs. In this paper, we choose super efficiency DEA model to study the performance of the listed new energy automobile company in China. The model is input oriented.

Suppose that there are $n$ kind of companies, each company $j(j=1,2, \cdots, n)$ inputs $m$ kinds of factors of production $X_{i j}(i=1,2, \cdots, m)$ and produces $s$ kind of output $Y_{r j}(r=1,2, \cdots, s)$. Expressions of super efficiency DEA model are showed as follows:

$$
\begin{array}{cc}
\min \theta_{0}^{\text {super }} & \\
\text { s.t. } \sum_{\substack{j=1 \\
j \neq 0}}^{n} \lambda_{j} X_{i j}+S_{i}^{-}=\theta_{0}^{\text {super }} X_{i 0} \\
\sum_{\substack{j=1 \\
j \neq 0}}^{n} \lambda_{j} Y_{r j}-S_{r}^{+}=Y_{r 0} \\
\sum_{j \neq 0} \lambda_{j}=1 \\
\lambda_{j}, S_{i}^{-}, S_{r}^{+} \geq 0, j \neq 0
\end{array}
$$

Equation (1) is the expression of super efficiency DEA model, and $\theta_{0}^{\text {super }}$ is the super efficiency values of $\mathrm{DMU}_{0}$. In equation (2), $S_{i}^{-}, S_{r}^{+}$are the slack variables.

\subsection{Malmquist Productivity Index}

The Malmquist index was developed by Swedish economist Malmquist in 1953. It based on the distance function which regarded as a kind of consumption index. Caves and Fare applied it to calculate the index of multiple inputs and outputs of the total productivity change. Total factor productivity (TFP) refers to the comprehensive productivity. It is widely applied to the enterprise productivity. Study on the window period of $S$ to $T$, of variable returns to scale, output oriented Malmquist index can be defined as:

$$
m(y s, x s, y t, x t)=\left[\frac{d_{s}^{C}\left(y_{t}, x_{t}\right) d_{s}^{C}\left(y_{s}, x_{s}\right)}{d_{t}^{C}\left(y_{t}, x_{t}\right) d_{t}^{C}\left(y_{s}, x_{s}\right)}\right]^{1 / 2}\left[\frac{d_{s}^{C}\left(y_{t}, x_{t}\right) d_{s}^{V}\left(y_{s}, x_{s}\right)}{d_{t}^{V}\left(y_{t}, x_{t}\right) d_{t}^{C}\left(y_{s}, x_{s}\right)}\right]\left[\frac{d_{s}^{V}\left(y_{t}, x_{t}\right)}{d_{t}^{V}\left(y_{s}, x_{s}\right)}\right]
$$


Equation (3) is the expression of Malmquist index. $d^{C}(y, x)$ is the distance function that under the invariable situation of returns to scale, $d^{v}(y, x)$ is the distance function of variable returns to scale. The expression for the first term is "technological progress". The second is scale efficiency change; The third is "pure technical efficiency change". Total factor productivity (TFP) can be decomposed into technological progress, pure technical efficiency and scale efficiency change. Technical efficiency change is further decomposed into pure efficiency change and scale efficiency change. When the technical efficiency change is greater than 1 , it indicates that $T$ period is much more close to the production surface relative to the $S$ period, explained that the enterprise has improved the efficiency due to the effective management and decision. Otherwise is invalid. The same as the technical efficiency change. When it is greater than 1 , indicates that the enterprise improve its efficiency due to technological progress, and vice versa. When total factor productivity is greater than 1 , it shows that total factor productivity is increased, and vice versa is reduced.

\subsection{Choosing Evaluation Indexes}

The key research and analysis of DEA model is to select the input and output indicators reasonably. This paper follows some principles when select the indicators, such as the index should reflect the competitiveness level of DMU objectively. The data can be obtained, Moreover this paper selects the following indicators based on literature and experts' consultations.

1) The input index

For enterprises, investment of resources can be divided into human resources, material resources and financial resources. Therefore, the input index can define into the number of employees $(X 1)$, total assets $(X 2)$, the main business costs $(X 3)$. Every employee in the enterprise carries out their duties to bring the enterprise benefit. The total assets of the enterprise including the fixed assets, current assets, intangible assets and other material resources, The total assets is the basis of enterprise management and development. Main business cost refers to all the expenses occurred by company's main business in the production and business operation process, including the production of raw materials, the sales cost and other costs. This index reflects the enterprise's financial resources from the angle of investment cost.

2) The output index

Standing in the perspective of stakeholders, the enterprises output can measured for its contribution to the stakeholders. Stakeholders of the firm are mainly divided into shareholders, employees, creditors and the government. Accordingly, the output indicators divided into net profit ( $Y 1)$, employee compensation $(Y 2)$, interest expenses (Y3) and income tax expense (Y4).

\subsection{Research Object and the Data Source}

The new energy automotive industry chain involves in many enterprises. The sample comes from the new energy automotive industry plate in Shanghai and Shenzhen stock market. The sample also refers to the "2013 energy-saving and new energy vehicles Year book". The sample excludes ST companies, a serious lack of data and incomplete disclosure of the company. Finally the paper selects 36 companies as the research samples. All the data come from financial statement of these 36 listing corporation from 2011-2013.

\section{Empirical Analysis}

Based on the input oriented DEA-BCC model, this paper uses DEAP 2.1 software to measure the output management efficiency of 36 new energy automobile industry listing corporations in 2013. The article also figures out the technical efficiency, the pure technical efficiency and scale efficiency value of each DMU. In DEA evaluation, while technical efficiency is equal to 1 , the production of the enterprise is efficient, and we called it DEA effectively. Otherwise if the technical efficiency is less than 1, the production of the enterprise is inefficient. Due to there are more than one efficiency value of new energy mobile listing corporation, in order to calculate the efficiency value further, this paper uses EMS software to calculates the super efficiency DEA on DMU. The DEA efficiency and calculation efficiency of super DEA are as shown in Table 1.

\subsection{Analysis of DEA Model}

From the overall perspective, in 2013, 9 of the 36 new energy automotive listed companies are DEA effective, it 
Table 1. The DEA efficiency super DEA efficiency of new energy automotive industry listing corporation.

\begin{tabular}{|c|c|c|c|c|c|c|}
\hline DMU & $\begin{array}{l}\text { Overall } \\
\text { Efficiency }\end{array}$ & $\begin{array}{l}\text { Pure Technical } \\
\text { Efficiency }\end{array}$ & Scale Efficiency & Scale & $\begin{array}{c}\text { The Super } \\
\text { Efficiency (\%) }\end{array}$ & $\begin{array}{c}\text { The Efficiency } \\
\text { Rating }\end{array}$ \\
\hline Inovance Technology & 1 & 1 & 1 & - & 2.554 & 1 \\
\hline Wanxiang Qianchao & 1 & 1 & 1 & - & 2.318 & 2 \\
\hline Xiamen Tungsten & 0.947 & 1 & 0.947 & drs & 2.098 & 3 \\
\hline Nari Technology & 1 & 1 & 1 & - & 2.06 & 4 \\
\hline BYD & 0.554 & 1 & 0.554 & drs & 2.001 & 5 \\
\hline Rongxin Power Electronic & 1 & 1 & 1 & - & 1.834 & 6 \\
\hline Auto Electric Power Plant & 0.452 & 1 & 0.452 & irs & 1.29 & 7 \\
\hline Zhongheng Electric & 0.601 & 1 & 0.601 & irs & 1.238 & 8 \\
\hline Xiamen Faratronic & 1 & 1 & 1 & - & 1.226 & 9 \\
\hline Ningbo Yunsheng & 1 & 1 & 1 & - & 1.1 & 10 \\
\hline Sieyuan Electric & 0.924 & 1 & 0.924 & drs & 1.017 & 11 \\
\hline Hainan Sundiro Holding & 0.92 & 1 & 0.92 & irs & 1 & 12 \\
\hline $\begin{array}{l}\text { Qinghai Salt Lake } \\
\text { Industry Group }\end{array}$ & 1 & 1 & 1 & - & 1 & 13 \\
\hline Shanghai General Motors & 1 & 1 & 1 & - & 1 & 14 \\
\hline $\begin{array}{l}\text { Inner Mongolia Baotou } \\
\text { Steel Rare-Earth }\end{array}$ & 0.744 & 0.993 & 0.749 & drs & 0.993 & 15 \\
\hline Anhui Jianghuai Automobile & 0.851 & 0.99 & 0.859 & drs & 0.99 & 16 \\
\hline Zhejiang Founder Motor & 0.154 & 0.948 & 0.163 & irs & 0.948 & 17 \\
\hline Jiangsu Guotai & 0.927 & 0.94 & 0.985 & irs & 0.94 & 18 \\
\hline Anyuan Coal Industry Group & 0.737 & 0.887 & 0.831 & drs & 0.887 & 19 \\
\hline Ningbo Joyson Electronic & 0.797 & 0.822 & 0.97 & drs & 0.822 & 20 \\
\hline Shenzhen Clou Electronices & 0.688 & 0.797 & 0.864 & irs & 0.797 & 21 \\
\hline $\begin{array}{c}\text { Zhongshan } \\
\text { Broad-Ocean Motor }\end{array}$ & 0.762 & 0.791 & 0.963 & irs & 0.791 & 22 \\
\hline Henan Senyuan & 0.785 & 0.91 & 0.863 & irs & 0.765 & 23 \\
\hline XJ Electric & 0.661 & 0.722 & 0.915 & drs & 0.722 & 24 \\
\hline $\begin{array}{c}\text { Xiamen King } \\
\text { Long Motor Group }\end{array}$ & 0.706 & 0.773 & 0.913 & drs & 0.722 & 25 \\
\hline Nantong Jianghai Capacitor & 0.526 & 0.707 & 0.745 & irs & 0.707 & 26 \\
\hline Jiangxi Ganfeng Lithium & 0.415 & 0.815 & 0.509 & irs & 0.656 & 27 \\
\hline Jiangxi Special Electric Motor & 0.257 & 0.59 & 0.436 & irs & 0.587 & 28 \\
\hline Sino-Platinum Metals & 1 & 1 & 1 & - & 0.581 & 29 \\
\hline Ningbo Shanshan & 0.519 & 0.536 & 0.968 & irs & 0.536 & 30 \\
\hline Beiqi Foton Motor & 0.429 & 0.535 & 0.802 & drs & 0.524 & 31 \\
\hline Dongfeng Automobile & 0.742 & 0.816 & 0.909 & drs & 0.456 & 32 \\
\hline ZhongTong Bus \& Holding & 0.309 & 0.42 & 0.736 & irs & 0.42 & 33 \\
\hline $\begin{array}{l}\text { Shanghai Tongji Science \& } \\
\text { Technology Industrial }\end{array}$ & 0.572 & 0.783 & 0.73 & irs & 0.313 & 34 \\
\hline Lanzhou Greatwall Electrical & 0.18 & 0.292 & 0.616 & irs & 0.292 & 35 \\
\hline Zhuzhou Times New Materials & 0.26 & 0.346 & 0.752 & irs & 0.233 & 36 \\
\hline Mean & 0.706 & 0.845 & 0.824 & & & \\
\hline
\end{tabular}


accounts for $25 \%$ of the total and the average comprehensive performance scores 0.706 , indicating that these 9 decision units are in the efficient production frontier. The remaining 27 companies are non DEA effective, indicating this 27 enterprises resources have not reached the optimal configuration. They can still improve and optimize the allocation of resources. The least level of comprehensive technical efficiency is the Great Wall electrician which only scores 0.18 . The overall result shows that the level of resource configuration of new energy automotive listing corporation is not high.

According to the data in Table 1, we can divide the new energy automotive listing corporation into three categories:

The first class is the pure technical efficiency and the scale efficiency are less than 1 . It means that the scale and efficiency of the company are invalid. There are Baotou Steel Rare Earth, Jianghuai Automobile, founder motor, Xu Ji electric, Jinlong automobile, Zhongtong bus, Tongji Science and technology company. On the one hand, the allocation of resource of these companies is not rational. On the other hand, the level of management efficiency of these companies is not high, the scale of operation needs to be improved. In order to improve the operating efficiency, the companies need to expand the scale.

The second category is the pure technical efficiency scoring 1 but the scale efficiency less than 1 . There are 6 companies belong to this category. The allocation of resource of these companies is relatively efficient. Xiamen tungsten industry, BYD, Siyuan electric listing companies are in the decreasing returns to scale stage, indicating that the allocation of resources of these companies is not reasonable. The outspread rate is too rapid and resource utilization rate is too low. Therefore, these companies need to improve efficiency by downsizing properly. Auto Electric Power Plant, Hainan Sundiro Holding are at the stage of increasing returns to scale, it improves that the development trend of the enterprise is good, these companies can increase the output by increasing the human capital and other production factors, so as to improve the performance of the company.

The third category is the scale efficiency and pure technical efficiency scoring 1 . It means that the integrated technical efficiency value is 1 , and the scale and efficiency of these companies are effective. There are 8 companies belong to this type. The size of configuration and the factor of production resources are in the most efficient state. In order to calculate and distinguish these effective decision unit values further. This paper uses super efficiency DEA model to analyze the effective decision unit values.

\subsection{Super Efficiency DEA Results and Analysis}

The super efficiency DEA model can further compare the multiple effective decision unit, which will calculate the grasp of the new energy automotive industry listing corporation operating efficiency accurately. In this paper, we use EMS 1.3 software to calculate super efficiency DEA. Seen from Table 1, the rank of comprehensive efficiency of super DEA is almost same as the traditional efficiency DEA. The top few are Inovance Technology, Wanxiang Qianchao, Xiamen Tungsten Nari Technology, BYD, Rongxin Power Electronic, Auto Electric Power Plant, Zhongheng Electric, Xiamen Faratronic, Ningbo Yunsheng. The efficiency of these companies is relatively high. The main reason is that these companies mainly focused on research and development. As a strategic emerging industry, research and development ability are the key to obtain the competitive. For example, Huichuan technology company has the research and development advantages in the new energy vehicle field to meet the customer's demand. Therefore, it had got the key customers order in 2013. As "China's Tesla", the development of Wanxiang Qianchao is also very optimistic. After acquisition the part of battery technology of Leiden energy company, it is expected to strengthen technical reserves in the automotive industry. Xiamen tungsten as the upstream supply chain enterprises of new energy automobile industry is the leading enterprises producing Ni MH battery hydrogen storage powder in domestic. Once the new energy automotive industry have developed, Xiamen tungsten industry will expand rapidly. In addition, as the charging station leader, Nari, absolutely is the beneficiaries of the development of new energy automotive industry.

\subsection{Malmquist Index}

On the basis of DEA research to obtain static operating efficiency the new energy automobile industry listing corporation, this paper will use DEA 2.1 software to calculation the Malmquist productivity index of the new energy automotive industry listing corporation from 2011 to 2013. The calculated results are shown in Table 2. The analysis of Table 2 shows as followed.

First, from 2011 to 2013, the average total factor productivity of new energy automobile industry listing cor- 
Table 2. Malmquist productivity index of new energy automotive industry listing corporation from 2011 to 2013.

\begin{tabular}{|c|c|c|c|c|c|}
\hline DMU & $\begin{array}{l}\text { Technical } \\
\text { Efficiency }\end{array}$ & $\begin{array}{l}\text { Technological } \\
\text { Progress }\end{array}$ & $\begin{array}{l}\text { Pure Technical } \\
\text { Efficiency }\end{array}$ & Scale Efficiency & $\begin{array}{l}\text { Total Factor } \\
\text { Productivity }\end{array}$ \\
\hline Shenzhen Clou Electronices & 1.489 & 1.1 & 1.53 & 0.973 & 1.637 \\
\hline Rongxin Power Electronic & 1 & 1.444 & 1 & 1 & 1.444 \\
\hline Wanxiang Qianchao & 1.073 & 1.272 & 1 & 1.073 & 1.365 \\
\hline ZhongTong Bus \& Holding & 1.543 & 0.851 & 1.474 & 1.047 & 1.314 \\
\hline XJ Electric & 1.642 & 0.798 & 1.748 & 0.939 & 1.311 \\
\hline Anhui Jianghuai Automobile & 1.276 & 0.944 & 1.155 & 1.105 & 1.205 \\
\hline Zhongheng Electric & 1.722 & 0.656 & 1 & 1.722 & 1.13 \\
\hline Dongfeng Automobile & 1.325 & 0.852 & 1.24 & 1.069 & 1.13 \\
\hline Lanzhou Greatwall Electrical & 1.123 & 0.97 & 1.126 & 0.997 & 1.089 \\
\hline Nantong Jianghai Capacitor & 1.66 & 0.653 & 1.383 & 1.2 & 1.084 \\
\hline Inovance Technology & 1 & 1.074 & 1 & 1 & 1.074 \\
\hline Ningbo Joyson Electronic & 1.336 & 0.785 & 1.129 & 1.184 & 1.049 \\
\hline BYD & 0.966 & 1.083 & 1 & 0.966 & 1.046 \\
\hline Zhongshan Broad-Ocean Motor & 1.105 & 0.922 & 1.096 & 1.009 & 1.018 \\
\hline Jiangxi Special Electric Motor & 1.384 & 0.731 & 1.122 & 1.233 & 1.011 \\
\hline Henan Senyuan & 1.272 & 0.791 & 1.116 & 1.14 & 1.006 \\
\hline Sieyuan Electric & 0.961 & 1.034 & 1 & 0.961 & 0.993 \\
\hline Xiamen King Long Motor Group & 1.033 & 0.951 & 0.946 & 1.092 & 0.982 \\
\hline Nari Technology & 1.264 & 0.773 & 1.224 & 1.032 & 0.977 \\
\hline Xiamen Faratronic & 1.15 & 0.85 & 1 & 1.15 & 0.977 \\
\hline Qinghai Salt Lake Industry Group & 1.045 & 0.931 & 1 & 1.045 & 0.973 \\
\hline Beiqi Foton Motor & 0.955 & 1.015 & 0.921 & 1.037 & 0.969 \\
\hline Auto Electric Power Plant & 0.825 & 1.173 & 1 & 0.825 & 0.968 \\
\hline Sino-Platinum Metals & 1.112 & 0.871 & 1 & 1.112 & 0.968 \\
\hline Jiangxi Ganfeng Lithium & 1.317 & 0.733 & 0.917 & 1.436 & 0.965 \\
\hline Ningbo Shanshan & 0.72 & 1.266 & 0.745 & 0.966 & 0.912 \\
\hline Ningbo Yunsheng & 1 & 0.895 & 1 & 1 & 0.895 \\
\hline Hainan Sundiro Holding & 0.959 & 0.926 & 1 & 0.959 & 0.889 \\
\hline Xiamen Tungsten & 1.127 & 0.762 & 1.078 & 1.045 & 0.858 \\
\hline Anyuan Coal Industry Group & 0.987 & 0.838 & 1.021 & 0.967 & 0.826 \\
\hline Jiangsu Guotai & 0.963 & 0.802 & 0.963 & 1 & 0.772 \\
\hline $\begin{array}{l}\text { Shanghai Tongji Science \& } \\
\text { Technology Industrial }\end{array}$ & 1.241 & 0.585 & 1.144 & 1.085 & 0.726 \\
\hline Zhejiang Founder Motor & 0.737 & 0.887 & 0.606 & 1.216 & 0.654 \\
\hline Inner Mongolia Baotou Steel Rare-Earth & 0.862 & 0.554 & 0.997 & 0.865 & 0.477 \\
\hline Shanghai General Motors & 1 & 0.435 & 1 & 1 & 0.435 \\
\hline Zhuzhou Times New Materials & 0.51 & 0.852 & 0.51 & 0.999 & 0.434 \\
\hline Mean & 1.098 & 0.867 & 1.037 & 1.058 & 0.951 \\
\hline
\end{tabular}


poration scores 0.951 . It shows a negative growth of total factor productivity from 2011 to 2013. Total factor productivity of these three years has decreased by $4.9 \%$. By the same token, technical efficiency increased by $9.8 \%$, but technical progress rate decreased by $13.3 \%$. It suggests that the reduction of total factor productivity is the main reason for the decline of the rate of technological progress. Technological progress has become the key factor of further development of new energy automotive industry.

Second, there are 16 of 36 new energy automobile industry listing corporations achieve positive growth in total factor productivity. According to the relevant theory, when total factor productivity index falls in the interval [1.025, + infinity], it is considered that Malmquist productivity index has obviously risen. When the total factor productivity index falls in the range of [0, 0.975], it is considered that the index has obviously decreased. While the total factor productivity index falls in the interval $(0.975,1.025)$, the index change is relatively stable. Data showed the total factor productivity of following companies rises obviously: Clou Electronices, Rongxin Power, Wanxiang Qianchao, ZhongTong Bus \& Holding, XJ Electric, Jianghuai Automobile, Zhongheng Electric, Dongfeng Automobile, Lanzhou Greatwall Electrical, Nantong Jianghai Capacitor, Inovance Technology, Ningbo Joyson Electronic, BYD. However, the total factor productivity of Jiangsu Guotai, Tongji Science \& Technology, Founder Motor declines obviously. This shows that the development of new energy automotive industry listing corporation is not balanced.

Third, from the decision-making unit, the total factor productivity of CLOU electronics grows fastest. It is $63.7 \%$. It all comes down to the technical efficiency increase (increased by $48.9 \%$ ), while the technical efficiency increase is mainly due to pure technical efficiency growth (increased by 53\%). On the whole, there are 16 listing corporation's total factor productivity growth rate greater than 1 . Relative to other listing corporation, the decline of technology progress of these 16 companies is narrow. Therefore, the technological progress rate directly determines the level of total factor productivity value and the change value of new energy automotive industry.

\section{Conclusions and Recommendations}

\subsection{Conclusions}

This article carries on the analysis and evaluation of operating performance of 36 new energy automobile industry listing corporation on the base on super efficiency DEA and Malmquist index method.

The empirical results show that there are only 9 listing corporations reached DEA effectively among 36 new energy automobile industry listing corporations. From the overall perspective, the performance of new energy automotive industry is general. From the super efficiency value point of view, even DEA effective companies still have to improve the efficiency. From the Malmquist total factor productivity index, the average growth of total factor productivity of new energy auto industry listing corporation is $-4.9 \%$ from 2011 to 2013, the study finds that the rate of technological progress is an important cause of the decline of total factor productivity. The result shows that in new energy automobile industry, the productivity depends more on technical efficiency to some extent, while ignoring the importance of technological progress, technological progress has become the key factor restricting the new energy automotive industry for further development.

\subsection{Recommendations}

Although the new energy automotive industry in China has made positive progress, as a strategic emerging industry, the listing corporations are at the initial stage overall. In order to enhance the operational efficiency of new energy automobile enterprises, promote the long-term development of new energy automotive industry. Based on the empirical analysis results, this paper proposes the following suggestions from government, industry and enterprises perspective.

1) The government should strengthen regulation policy, establish and improve the system of technology innovation. As the enterprises input enormous cost in R \& D and market cultivation. On the one hand, the government should establish policy of the finance and taxation system reasonably, so that to reduce financial burdens on enterprises and guarantee the development of new energy vehicles. On the other hand, the government should establish the effective investment and financing system to the integrate capital resource, technical resource and other parties resources.

2) The development of the new energy automobile industry is inseparable from the charging network of urban 
infrastructure, the government should introduce relevant policies to encourage the construction of infrastructure of new energy automobile and reduce the new energy input costs. Moreover, the government should improve the efficiency of the whole management of new energy automobile companies, so that to enhance the overall competitiveness of new energy automobile industry and promote the development of new energy automotive industry.

3) From the evaluation results, Firstly, the new energy automobile enterprises should focus on technological progress, they have better increase technology research and development investment, and strengthen the independent innovation and technological upgrading. In addition, the companies should improve the efficiency of input and output of new energy automobile enterprises. Secondly, it is significant to cultivate high quality talents and scientific research team. What is more, establishing the mechanism of introducing talents is also critical. One of the feasible and effective way is to cooperate with of university in educating high-quality talents.

4) Last but not the least, the new energy automotive industry can establish industry alliance and integrate the advantage resources to strengthen the connection and cooperation of the industry chain. Only the whole new energy automobile industry chain makes balanced development can the new energy automobile enterprises cultivate core competence and promote the comprehensive development of the new energy automotive industry.

\section{References}

[1] Jia, L.J. and Lv, R.Z. (2014) New Energy Vehicle Takes Great Leap Forward. Automobile \& Parts, 14, 32-36.

[2] Zhang, G.Q. and Zhang, X. (2014) Path Dependence and Solutions Faced by Development of New-Energy Automobile Industry. Journal of Industrial Technological Economics, 2, 75-80.

[3] Sharma, S. (2004) A Study on Productivity Performance of Indian Automobile Industry: Growth Accounting Analysis. APPC 2004 Conference Program, Hanoi, Vietnam, 25-31 October 2004.

[4] Papahristodoulou, C. (1997) A DEA Model to Evaluate Car Efficiency. Applied Economics, 29, 1493-1508. http://dx.doi.org/10.1080/000368497326327

[5] Orsato, R.J. and Wells, P.U. (2007) The Rise and Demise of the Automobile Industry. Journal of Cleaner Production, 15, 994-1006. http://dx.doi.org/10.1016/j.jclepro.2006.05.019

[6] Saranga, H. (2009) The Indian Auto Component Industry_Estimation of Operational Efficiency and Its Determinants Using DEA. European Journal of Operational Research, 196, 707-718. http://dx.doi.org/10.1016/j.ejor.2008.03.045

[7] Nandy, D. (2011) Efficiency Study of Indian Automobile Companies Using DEA Technique: A Case Study of Select Companies. The IUP Journal of Operations Management, 10, 39-50.

[8] Wang, Y. and Ji, Y. (2010) Study on Efficiency of Chinese Automobile Industry Listing Corporation. Commercial and Research, 12, 97-101.

[9] Li, Z.H. (2012) Research on the Construction and Innovation Path Selection Evaluation of Multidimensional Model of China Automobile Industry. Ph.D. Thesis, Wuhan University of Technology, Wuhan.

[10] Wu, X.J. and Chen, X.L. (2011) An Empirical Analysis of Total Factor Productivity and the Impact of China's Automobile Industry. Research on Financial and Economic Issues, 3, 41-45.

[11] Yang, P. and Ke, C.Y. (2011) SWOT Analysis China's Development of New Energy Vehicles in the Post Crisis Era. Exploration of Economic Problems, 3, 18-23.

[12] Ru, X.J. (2010) Research on Comprehensive Evaluation of New Energy Automotive Technology Economy and Its Development Strategy. Ph.D. Thesis, Wuhan University of Technology, Wuhan.

[13] Wang, W. (2013) Research on Innovation Efficiency of New Energy Automobile Enterprise. Ph.D. Thesis, Harbin Institute of Technology, Harbin.

[14] Zhang, G.W. and Zeng, H.Y. (2014) Study on the Factors of New Energy Automobile Production Efficiency and Effects Based on DEA-Tobit Model. Industrial technology economy, 3, 130-137.

[15] Quo, Q.F. (2014) Research on the Business Model of Development of the New Energy Automobile Industry. Special Zone Economy, 7, 45-47.

[16] Li, Y., Song, J. and Yang, J. (2012) Progress in Research on the Performance and Service Life of Batteries Membrane of New Energy Automotive. Chinese Science Bulletin, 57, 4153-4159. http://dx.doi.org/10.1007/s11434-012-5448-9

[17] Li, Y., Song, J. and Yang, J. (2014) A Review on Structure Model and Energy System Design of Lithium-Ion Battery in Renewable Energy Vehicle. Renewable and Sustainable Energy Reviews, 37, 627-633. http://dx.doi.org/10.1016/j.rser.2014.05.059

[18] Liuqin, C. and Bing, X. (2012) China’s New Energy Vehicle Industry: Problems and Challenges. Electric (English 
version), 33.

[19] Gong, H., Wang, M.Q. and Wang, H. (2013) New Energy Vehicles in China: Policies, Demonstration, and Progress. Mitigation and Adaptation Strategies for Global Change, 18, 207-228. http://dx.doi.org/10.1007/s11027-012-9358-6

[20] Gu, L.Z. and Shao, Y.F. (2014) The Analysis of Innovation Policies for New Energy Vehicle Technology. Studies in Sociology of Science, 5, 147-151.

[21] Xi, X. and Zhao, J.Y. (2014) Breaking the Existing Regional Technological Regime with Effective Policy-Making: A Case Study on New-Energy Vehicle Manufacturing in Jilin Province. 2014 IEEE International Conference on Management Science \& Engineering (ICMSE), Helsinki, 17-19 August 2014, 2102-2109. 
Scientific Research Publishing (SCIRP) is one of the largest Open Access journal publishers. It is currently publishing more than 200 open access, online, peer-reviewed journals covering a wide range of academic disciplines. SCIRP serves the worldwide academic communities and contributes to the progress and application of science with its publication.

Other selected journals from SCIRP are listed as below. Submit your manuscript to us via either submit@scirp.org or Online Submission Portal.
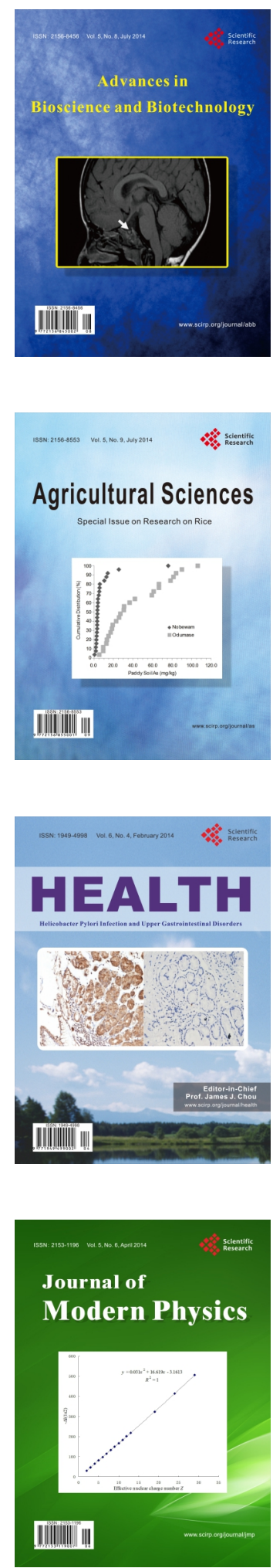
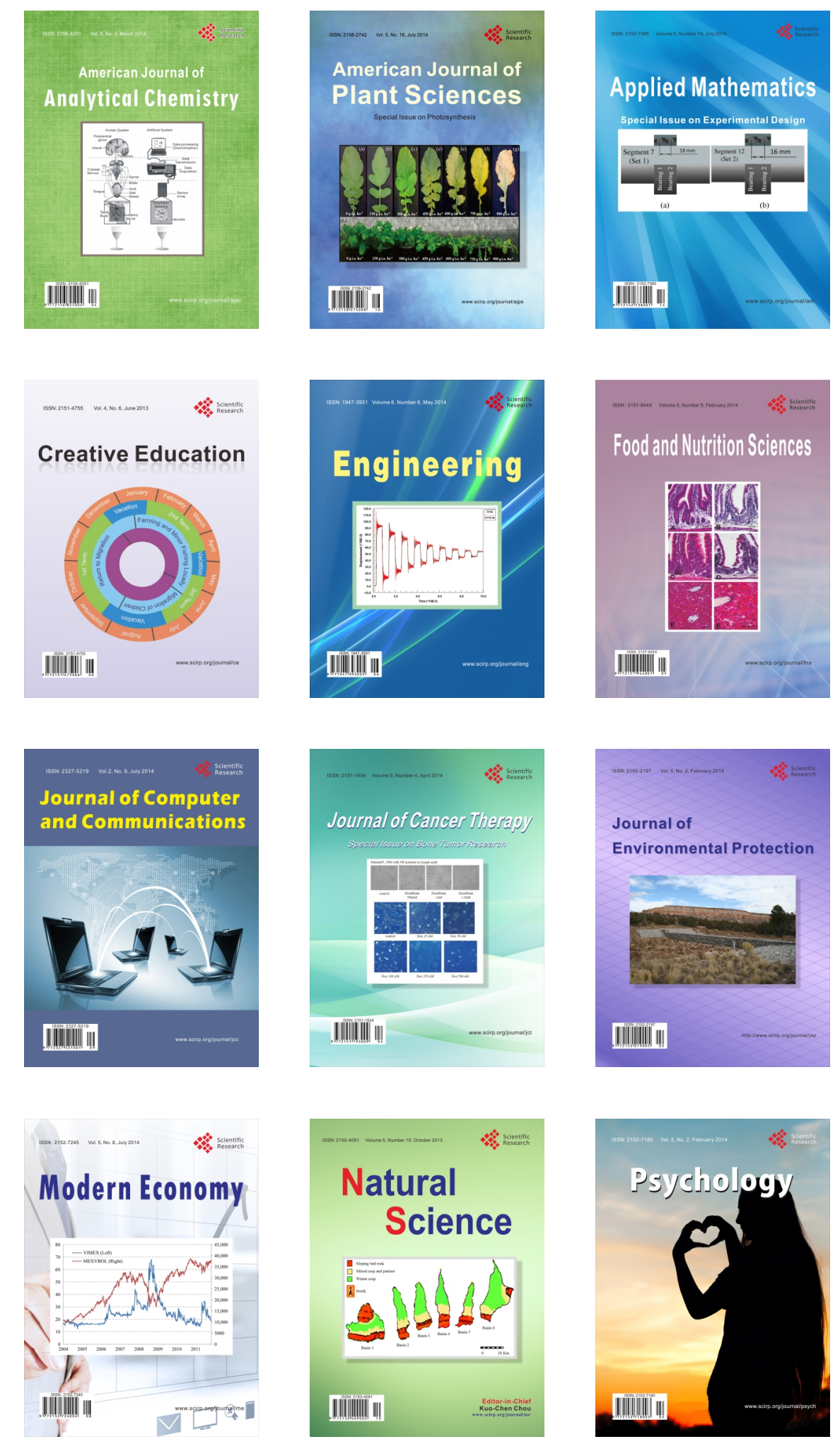